\title{
Geothermal ecosystems as natural climate change experiments: The ForHot research site in Iceland as a case study
}

\author{
BJarni D. Sigurdsson ${ }^{1}$, Niki I. W. Leblans ${ }^{1,2}$, Steven Dauwe ${ }^{1,2}$, Elín GuĐMundsdótTir ${ }^{3}$, \\ Per Gundersen $^{4}$, Gunnhildur E. Gunnarsdóttir ${ }^{1}$, Martin Holmstrup ${ }^{5}$, \\ Krassimira Ilieva-MaKulec ${ }^{6}$, Thomas KäTterer ${ }^{7}$, Bryndís MarteinsdótTir ${ }^{8}$, \\ Marja Maljanen ${ }^{9}$, Edda S. Oddsdóttir ${ }^{10}$, IVika Ostonen ${ }^{11}$, Josep Peñuelas ${ }^{12,13}$, \\ Christopher Poeplau ${ }^{14}$, Andreas Richter ${ }^{15}$, Páll SigurĐsson ${ }^{1}$, Peter Van Bodegom ${ }^{16}$, \\ HÅKAN WALLANDER ${ }^{17}$, JAMES WEEdon ${ }^{18}$, IVAN JANSSENS ${ }^{2}$ \\ ${ }^{1}$ Agricultural University of Iceland, Hvanneyri, IS-311 Borgarnes, Iceland.bjarni@lbhi.is (corresponding author) \\ ${ }^{2}$ Department of Biology, University of Antwerp, Belgium; ${ }^{3}$ East Iceland Nature Research Centre, Neskaupstadur, Iceland; \\ ${ }^{4}$ Department of Geosciences and Natural Resource Management, University of Copenhagen, Denmark; ${ }^{5}$ Department \\ of Bioscience - Soil Fauna Ecology and Ecotoxicology, Aarhus University, Silkeborg, Denmark; ${ }^{6}$ Institute of Ecology \\ and Bioethics, Cardinal St. Wyszynski University in Warsaw, Poland; ${ }^{7}$ Department of Ecology, the Swedish University of \\ Agricultural Sciences, Uppsala, Sweden; ${ }^{8}$ Institute of Life and Environmental Sciences, University of Iceland, Reykjavik, \\ Iceland; ${ }^{9}$ University of Eastern Finland, Kuopio, Finland; ${ }^{10}$ Icelandic Forest Research, Mógilsá, Reykjavik, Iceland; ${ }^{11}$ \\ University of Tartu, Estonia; ${ }^{12}$ CSIC, Global Ecology Unit CREAF-CSIC-UAB, Bellaterra (Catalonia), Spain; ${ }^{13}$ CREAF, \\ Cerdanyola del Vallès (Catalonia), Spain; ${ }^{14}$ Thünen Institute of Climate-Smart Agriculture, Braunschweig, Germany; ${ }^{15}$ \\ Department of Microbiology and Ecosystem Science, University of Vienna, Austria; ${ }^{16}$ Institute of Environmental Sciences, \\ Leiden University, the Netherlands; ${ }^{17}$ Department of Biology, Lund University, Lund, Sweden; ${ }^{18}$ Department of Ecological \\ Science, VU University Amsterdam, the Netherlands.
}

\begin{abstract}
This article describes how natural geothermal soil temperature gradients in Iceland have been used to study terrestrial ecosystem responses to soil warming. The experimental approach was evaluated at three study sites in southern Iceland; one grassland site that has been warm for at least 50 years (GO), and another comparable grassland site $(\mathrm{GN})$ and a Sitka spruce plantation $(\mathrm{FN})$ site that have both been warmed since an earthquake took place in 2008. Within each site type, five ca. $50 \mathrm{~m}$ long transects, with six permanent study plots each, were established across the soil warming gradients, spanning from unwarmed control conditions to gradually warmer soils. It was attempted to select the plots so the annual warming levels would be ca. $+1,+3,+5,+10$ and +20 ${ }^{\circ} \mathrm{C}$ within each transect. Results of continuous measurements of soil temperature (Ts) from 2013-2015 revealed that the soil warming was relatively constant and followed the seasonal Ts cycle of the unwarmed control plots. Volumetric water content in the top $5 \mathrm{~cm}$ of soil was repeatedly surveyed during 2013-2016. The grassland soils were wetter than the FN soils, but they had sometimes some significant warming-induced drying in the surface layer of the warmest plots, in contrast to FN. Soil chemistry did not show any indications that geothermal water had reached the root zone, but soil $\mathrm{pH}$ did increase somewhat with warming, which was probably linked to vegetation changes. As expected, the potential decomposition rate of organic matter increased significantly with warming. It was concluded that the natural geothermal gradients at the ForHot sites in Iceland offered realistic conditions for studying terrestrial ecosystem responses to warming with minimal artefacts.
\end{abstract}

Keywords: geothermal soil warming; subarctic grasslands; climate change; spruce forest; decomposition 


\section{ÚTDRÁTTUR}

Jarðhitavistkerfi sem náttúrulegar loftslagsbreytingatilraunir: ForHot verkefnið á Íslandi sem sýnidcemi. pessi grein lýsir pví hvernig jarðhitasvæði hérlendis hafa verið notuð til að rannsaka áhrif hlýnunar á norðlæg purrlendisvistkerfi. Rannsóknirnar fóru fram á premur stöðum í Ölfusi, í næsta nágrenni Hveragerðis: i) í graslendum sem hafa verið undir áhrifum jarðvegshlýnunar í langan tíma (GO), eða allavega í 50 ár, ii) í samskonar graslendum sem byrjuðu fyrst að hitna vorið 2008 eftir Suðurlandsskjálftann (GN) og iii) í gróðursettum 50 ára sitkagrenisskógi sem einnig byrjaði að hitna vorið 2008 (FN). Á hverjum stað voru lögð út fimm um 50 m löng snið, pvert á hitastigla svæðanna, og sex fastir mælireitir lagðir út á hverju sniði pannig að einn var á óupphituðum jarðvegi (samanburðarreitur) en hinir á síheitari jarðvegi. Reynt var að velja pannig að upphitunin yrði sem næst $+1,+3,+5,+10$ og $+20^{\circ} \mathrm{C}$. Samfelldar mælingar á jarðvegshita reitanna 2013-2015 sýndu að upphitunin hélst tiltölulega stöðug og jarðvegshiti peirra sveiflaðist líkt og í óupphituðum reitum milli árstíða. Vatnsinnihald yfirborðsjarðvegs (0-5 cm) var mælt reglulega yfir tímabilið 2013-2016. Graslendin höfðu að jafnaði rakari yfirborðsjarðveg en skógurinn, en pau, ólíkt skóginum, sýndu einnig stundum marktæka upppornun á heitustu reitunum. Efnagreiningar sýndu engin merki pess að jarðhitavatn næði upp í jarðveg svæðanna. Sýrustig jarðvegs hækkaði aðeins (varð basískara) með auknum hita sem tengdist líklega gróðurfarsbreytingum. Niðurbrotsgeta á lífrænu efni jókst með jarðvegshita í öllum reitunum, eins og búist var við. Lokaniðurstaðan var að jarðhitasvæði ForHot verkefnisins framkölluðu aðstæður sambærilegar við ýmsar stýrðar jarðvegsupphitunartilraunir erlendis sem notaðar eru til að rannsaka áhrif hlýnunar á purrlendisvistkerfi.

\section{INTRODUCTION}

The impacts of changing climatic conditions on terrestrial ecosystems at high latitudes $\left(>60{ }^{\circ} \mathrm{N}\right)$ are a very active research field today (Hyvönen et al. 2007, Way \& Oren 2010, Kayler et al. 2015). The typical cold conditions at high latitudes strongly constrain decomposition of organic material (McGuire et al. 2009) and over time this has led to the build-up of organicmatter rich soils with relatively slow nutrient cycles in this region. As a consequence, northern high latitude soils store almost $30 \%$ of the global soil carbon (C) stocks (Scharlemann et al. 2014), even if they only cover ca. $5 \%$ of the terrestrial global soil surface (CAFF 2013). It is still uncertain how fast these ecosystems will change in a warmer world (IPCC 2013), which makes them especially important to study.

Many different experimental approaches have been used to evaluate the effects of future warming on ecosystem structure and function including: i) monitoring of natural variation in temperature and ecosystem variables, ii) climate gradient studies, iii) process-based modelling of plant and ecosystem responses to warming, and iv) experimental indoor or outdoor warming of plants, soils or whole ecosystems (cf. Rustad 2008, De Boeck et al. 2014). Each method has its pros and cons, but there is a consensus among most ecosystem ecologists that in situ warming of ecosystem components and/or whole ecosystems is the most powerful tool that allows for the elucidation of cause-andeffect relationships and provides a mechanistic understanding of ecosystem responses to climate change (Rustad, 2008; Way \& Oren 2010, De Boeck et al. 2014). Manipulation experiments tend, however, to be technically challenging and expensive to run, which most often limit their duration to only a few years and include only one or a few warming levels (De Boeck et al. 2014).

Given that anthropogenic warming is occurring on a relatively short time scale, transient biological responses are likely in the initial stages (O'Gorman et al. 2014). Rustad (2008) stated in her review that there is a great need to conduct longer-term warming studies (decadal responses) in order to better understand changes that occur on multiannual time scales. Recently it has also been stressed that far too few in situ ecosystem warming experiments have been designed to impose warming gradients to identify possible response thresholds in ecosystem responses (De Boeck et al. 2014, Kayler et al. 2015). One possibility to meet both 
these requirements, i.e. studying decadal in situ effects to warming and to include large warming gradients, without requiring excessive funds and technological complexity, is to use ecosystems affected by natural geothermal activity.

There are, however, some challenges to using geothermal gradients as warming experiments, and of those we feel that four issues are especially important: i) Geothermal gradients can have existed for a very long time, even centuries or millennia, during which their communities and soils may have been shaped not only by temperature, but also by a myriad of other ecological and evolutionary factors operating at longer time scales (De Boeck et al. 2014, O'Gorman et al. 2014). Under such conditions, the geothermal gradients can function similarly to larger elevational or latitudinal gradients, even if they are spatially confined. Sometimes the time of the onset of the geothermal warming is known (Kayler et al. 2015), and then such gradients can offer comparable conditions to ecosystem manipulation studies that focus on annual to decadal responses to warming. ii) An advantage of geothermal gradients compared to most other natural temperature gradients is that they are much more confined in space, which reduces the potential influence of other confounding environmental factors (O’Gorman et al. 2014). This is only true, however, if geothermal water is not able to reach the soil and the root zone of the warmed plots, since it is typically rich in dissolved minerals that can have ecotoxic effects (Wetang'ula \& Snorrason 2005). iii) Geothermal gradients only warm the soil and thereby their effect on processes dominated by air temperature rather than soil temperature may be different from climate warming. This is also an issue with other types of soil warming experiments commonly used to study the effects of warming on ecosystems (Streit et al. 2013, Schindlbacher et al. 2015). iv) Geothermal gradients normally start with a stepwise change in soil temperature, which differs from the gradual changes of Earth's climate. This may affect how the ecosystem responses develop (De Boeck et al. 2014) and therefore it is important to include multiannual or decadal responses when such results are extrapolated in relation to climate change. Again, this is something that geothermal gradients have in common with other manipulation studies.

Some earlier manipulation experiments have shown that $\mathrm{N}$ limited northern ecosystems may respond to warming mainly through effects on soil processes (cf. Way \& Oren, 2010). For example, in a recent large-scale warming experiment on mature Norway spruce (Picea abies) forest in northern Sweden it was discovered that only increasing the air temperature did not significantly change tree volume growth (Sigurdsson et al. 2013), whereas, when only the soils were warmed at the same site, the forest productivity responded strongly (Strömgren \& Linder 2002). This was explained with soil warming enhancing $\mathrm{N}$ availability through increased soil organic matter decomposition and the strong $\mathrm{N}$ limitation that exists in most high-latitude ecosystems, which can override the direct effects of air temperature on aboveground processes. Recently, there have been various extensive experiments warming only the soil in different alpine and northern ecosystems (cf. Rustad 2001, Strömgren \& Linder 2002, Patil et al. 2013, Streit et al. 2013, Schindlbacher et al. 2015) as well as a few experiments warming both soils and aboveground air separately (Bronson \& Gower 2010, Krassovski et al. 2015).

Some research on either experimental or natural in situ warming has been carried out previously in Iceland, but never on such a large spatial scale or looking at as many terrestrial ecosystem levels as the ForHot project (e.g. Sigurdsson 2001, Bergh et al. 2003, Elmarsdottir et al. 2003, Jónsdóttir et al. 2005, Dalebeler et al. 2014, 2015). The most comparable work in Iceland is an ongoing project on naturally warmed stream ecosystems in the nearby Hengill area (e.g. Woodward et al. 2010, O'Gorman et al. 2014).

In this paper we address how stable the hourly to annual geothermal soil warming was at $10 \mathrm{~cm}$ depth at three different geothermal gradients in southern Iceland, as well as how 
the warming was distributed vertically, both in the soil and in the air above the study plots. Moreover, we address how other potential confounding environmental drivers were affected by the geothermal warming, including changes in soil $\mathrm{pH}$, soil humidity and if there were any indications of potential pollution by geothermal water in the soil profile, all of which can determine how suitable those sites are for

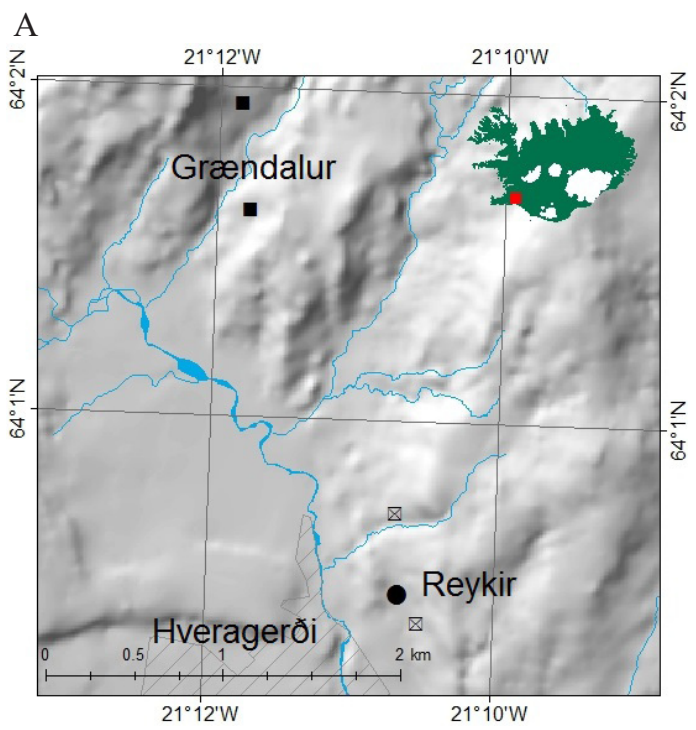

B

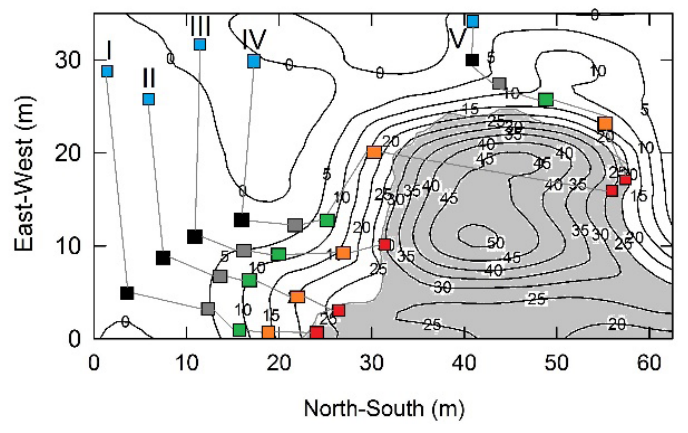

studying the effects of warming on terrestrial ecosystem structure and function.

\section{METHODS \\ Experimental setup}

The study sites were located in south Iceland, close to the village of Hveragerði $\left(64.008^{\circ} \mathrm{N}\right.$, $21.178^{\circ} \mathrm{W}$; 83-168 $\mathrm{m}$ a.s.1.), on the grounds of the Agricultural University of Iceland
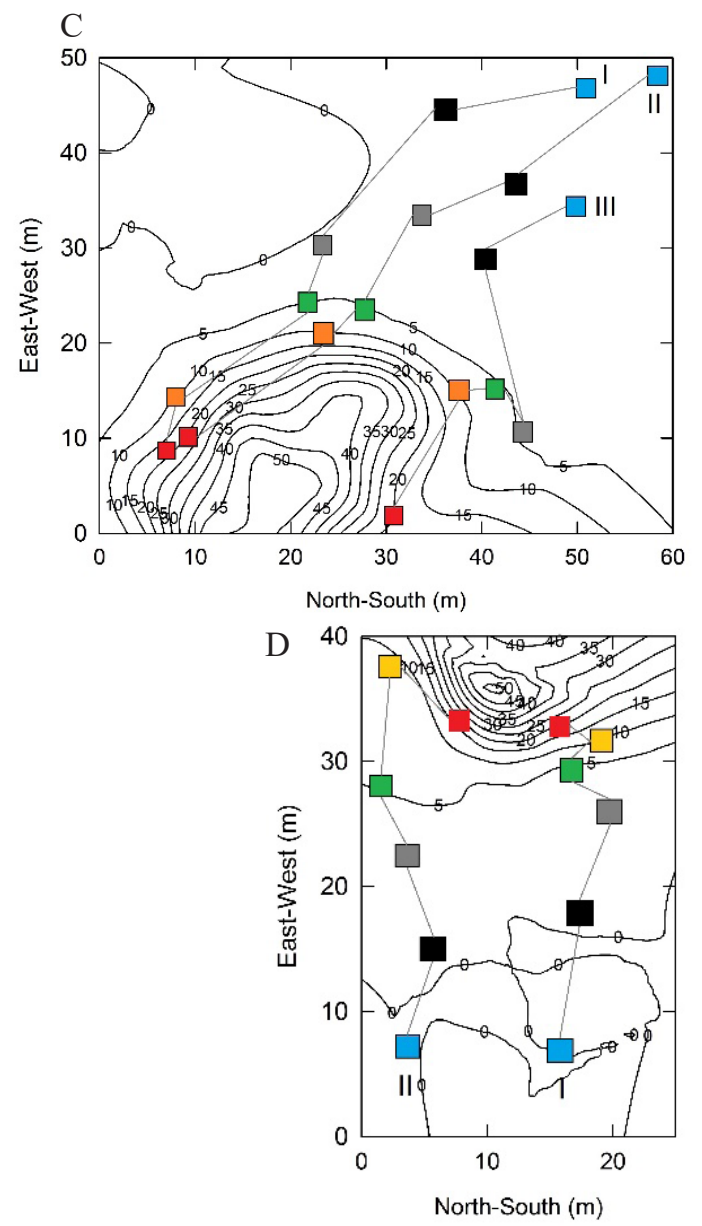

Figure 1. a) Location of the ForHot study sites in S Iceland. Filled circle is the recently warmed forest site (FN), crosshatched squares are the recently warmed grasslands (GN) and the filled squares are the near-by grasslands with long-term soil warming (GO) in Grændalur. The hatched area represents the village of Hveragerdi. b) Soil warming isotherms $\left({ }^{\circ} \mathrm{C}\right)$ at five transects within the FN site in spring 2012 and at c) three transects of the GN and d) two transects of the GO sites in spring 2014. Warming levels are A (unwarmed control; blue), B (black), $\mathrm{C}$ (grey), D (green), E (orange) and F (red). For evaluation of warming levels see Table 2. In FN, the natural background soil temperature (Ts) varied from -2 to $+2{ }^{\circ} \mathrm{C}$ because of stand density variation in the unwarmed forest stand and the actual geothermal warming was therefore ca. $2-4{ }^{\circ} \mathrm{C}$ lower than the isolines indicate. The shaded area for FN represents the area where Sitka spruce had died off in 2012. 
campus at Reykir (Figure 1). Between 2003 and 2015, the closest synoptic station at Eyrabakki (9 km S of Hveragerdi) had a mean annual air temperature (MAT), mean annual precipitation (MAP) and mean wind speeds of $+5.2{ }^{\circ} \mathrm{C}, 1457 \mathrm{~mm}$ and $6.6 \mathrm{~m} \mathrm{~s}^{-1}$, respectively (Icelandic Meteorological Office, 2016). The mean temperature of the warmest and coldest months, July and December, were $12.2{ }^{\circ} \mathrm{C}$ and $-0.1{ }^{\circ} \mathrm{C}$ for the same period. The mean monthly precipitation during May-July was 75 $\mathrm{mm}$ month $^{-1}$, while it was on average $135 \mathrm{~mm}$ month $^{-1}$ for the remaining months at Eyrabakki (Icelandic Meteorological Office, 2016). During the period of 1972-1999 both precipitation and air temperature were measured on the Reykir campus. During that period the MAT was similar $\left(0.1{ }^{\circ} \mathrm{C}\right.$ warmer $)$, but the MAP was on average $13 \%$ higher at Reykir (1616 $\mathrm{mm} \mathrm{year}^{-1}$ ) than at Eyrabakki (Icelandic Meteorological Office, 2016). The growing season normally starts in late May and ends in late August. Snow cover is not permanent during winters due to the mild oceanic climate, but the soil typically freezes for at least a couple of months during mid-winter.

On the 29 May, 2008, a major earthquake (magnitude 6.3 on the Richter scale) occurred in S Iceland (Halldorsson \& Sigbjörnsson 2009). The earthquake caused substantial damage to infrastructures and affected geothermal systems close to its epicentre. One such geothermal system at Reykir moved to a previously unwarmed area (Porbjörnsson et al. 2009), where the new geothermal bedrock channels resulted in increasing temperature (Ts) in the soil above by radiative heating (O'Gorman et al. 2014).

The recently warmed area is covered by two different site types: a) a Sitka spruce forest (Picea sitchensis, provenances Seward and Homer from Alaska) that was planted in 19661967 (Böðvar Gudmundsson, pers. comm.), hereafter termed "FN" (Forest New), and b) unmanaged treeless grasslands dominated by Agrostis capillaris grass, some herbs and moss (Table 1), hereafter termed "GN" (Grassland New). The soil type at both sites is Silandic Andosols (IUSS Working Group WBR 2015; a volcanic soil type, also known as Brown Andosol; Arnalds, 2015). It is silty loam in texture and has the typical characteristics of such soils in Iceland (Table 1; Arnalds 2015). The FN plantation was established mainly for shelter and has never been thinned. Therefore, it had a relatively high stand density, basal area and leaf area index (LAI) compared to typical managed spruce forests in Iceland or Scandinavia (Table 1; Snorrason \& Einarsson 2002, Weslien et al. 2009).

The third study site "GO" (Grassland Old) is located 2.0-2.5 km NW of GN and FN on older geothermal Ts gradients, in Grændalur (Figure 1 ). It is covered by the same grassland type as GN and on the same soil type (Table 1). There, the earliest survey of geothermal hot spots was made in 1963-1965 (45 years prior to the 2008 earthquake; Kristján Sæmundsson, pers. comm.). In autumn 2008, after the 2008 earthquake, the locations of the new and old geothermal hot spots in the area were remapped (Porbjörnsson et al. 2009). This survey was used to choose the GO, GN and FN sites for the ForHot study. Some hot spots at GO have been monitored since 2005 by regular field measurements of Ts in another study in Grændalur (Daebeler et al. 2014, 2015). The geothermal activity has most likely been persistent in Grændalur (Green valley) for centuries, as according to local knowledge its name comes from the fact that the subarctic grasslands on the warmest hot spots remain green during early winter and turn green sooner after the worst of winter has passed. The oldest historical document that mentions this place name was written in 1708 (Magnússon \& Vídalín, 1918-1921). Additional evidence for persistent geothermal warming at GO includes the geothermal clay layers found at various depths in the subsoil profile, thus indicating that over longer time periods, the warming may have fluctuated somewhat, as was observed at other nearby hot spots following the 2008 earthquake (Daebeler et al. 2014).

In autumn 2012 and spring 2013, twentyfive permanent study plots were established in each of the three site types (FN, GN and $\mathrm{GO}$ ), around one main hot spot in $\mathrm{FN}$ and in 
Table 1. Main plant and soil textural and chemical characteristics of the control plots (A plots) in the recently warmed forest (FN), grassland (GN), and long-term warmed grassland (GO) in 2013. Data from Cilio (2014), Guðmundsdóttir et al. (2014), Michielsen (2014) and Leblans (2016).

\begin{tabular}{|c|c|c|c|}
\hline & FN & GN & GO \\
\hline Soil type & Silandic Andosol & Silandic Andosol & Silandic Andosol \\
\hline Soil texture & Silt loam & Silt loam & Silt loam \\
\hline Clay:Silt:Sand ratio ${ }^{\text {a }}$ & $8: 61: 31 \%$ & $6: 53: 41 \%$ & $8: 62: 30 \%$ \\
\hline Stoniness in top $10 \mathrm{~cm}$ & $2.1 \%$ & $1.6 \%$ & $0.4 \%$ \\
\hline Bulk density in top $10 \mathrm{~cm}$ & $0.62 \mathrm{~g} \mathrm{~cm}^{-3}$ & $0.70 \mathrm{~g} \mathrm{~cm}^{-3}$ & $0.55 \mathrm{~g} \mathrm{~cm}^{-3}$ \\
\hline Topsoil C concentration $^{\mathrm{b}}$ & $7.1 \%$ & $5.4 \%$ & $5.1 \%$ \\
\hline Topsoil $\mathrm{N}$ concentration ${ }^{\mathrm{b}}$ & $0.47 \%$ & $0.49 \%$ & $0.44 \%$ \\
\hline Topsoil C/N ratio ${ }^{\mathrm{b}}$ & 15.1 & 10.9 & 11.5 \\
\hline $\begin{array}{l}\text { Three most dominant vascular plant } \\
\text { species }\end{array}$ & $\begin{array}{l}\text { Picea sitchensis } \\
\text { Understory: } \\
\text { Equisetum arvense-- } \\
\text { Geranium sylvaticum }\end{array}$ & $\begin{array}{l}\text { Agrostis capillaris } \\
\text { - Galium boreale } \\
- \text { Anthoxantum } \\
\text { odoratum }\end{array}$ & $\begin{array}{l}\text { Agrostis capillaris } \\
\text {-Galium boreale - } \\
\text { Ranunculus acris }\end{array}$ \\
\hline Vascular plant cover $^{\mathrm{c}}$ & $7 \%$ & $46 \%$ & $79 \%$ \\
\hline Moss cover & $5 \%$ & $88 \%$ & $62 \%$ \\
\hline LAI $^{\max }$ of veg. $>3 \mathrm{~cm}^{\mathrm{d}}$ & 5.4 & 6.0 & 5.8 \\
\hline Dominant height & $10.3 \mathrm{~m}$ & - & - \\
\hline Diameter at breast height & $12.6 \mathrm{~cm}$ & - & - \\
\hline Stand basal area & $49 \mathrm{~m}^{2} \mathrm{ha}^{-1}$ & - & - \\
\hline Stand density & 4.461 trees $\mathrm{ha}^{-1}$ & - & - \\
\hline
\end{tabular}

${ }^{\mathrm{a}}$ The standard methodology used here gives an underestimation for the true clay fraction in Andosol (Arnalds 2015); ${ }^{\mathrm{b}}$ 5-10 $\mathrm{cm}$ depth (only mineral soil); ${ }^{\mathrm{C}}$ Only including the ground vegetation in FN; ${ }^{\mathrm{d}}$ Determined by a LAI2200 instrument on $15-20$ Sept. 2016.

two separate hot-spots for GN and GO (Figure 1). The plots were placed along five ca. $50 \mathrm{~m}$ long transects placed perpendicular to the soil temperature gradients ranging from ambient soil temperature to $\sim+10^{\circ} \mathrm{C}$, placing five replicate plots at different warming levels (WLs) on each transect $\left(\sim+0,1,3,5\right.$ and $10^{\circ} \mathrm{C}$ warming; termed levels A (unwarmed control), B, C, D, and $\mathrm{E}$, respectively). In $\mathrm{GN}$ and $\mathrm{GO}$ the plots were $2 \times 2 \mathrm{~m}$ in size, but in FN they were $1 \times 1$ $\mathrm{m}$ and placed in between trees. In spring 2014 one additional WL was installed at each transect at $\sim+20{ }^{\circ} \mathrm{C}$ (termed level F), but those plots were all $1 \times 1 \mathrm{~m}$ in size due to the steeper soil warming gradients at the highest temperatures. This increased the number of permanent study plots to 30 per site type, or 90 across all three.

Both FN and GN transects were in areas which had been previously fenced and protected from livestock grazing, while Grændalur and its neighbouring areas are used as grazing commons and typically have 10-20 sheep from late May to late August. The areas containing the study plots at GO were therefore fenced off in spring 2013.

\section{Field measurements}

Soil temperatures were measured hourly adjacent to each plot at $10 \mathrm{~cm}$ soil depth using HOBO TidbiT v2 Water Temperature Data Loggers (Onset Computer Corporation, USA). Air temperature was measured close to the surface (at $2 \mathrm{~cm}$ and $15 \mathrm{~cm}$ ) at two plots at each warming level in each site type and at 2 $\mathrm{m}$ height in one to two places in each system, using the same type of loggers and logging frequency, but protected from direct sunlight with radiation shelters. Vertical soil temperature 
profiles were measured in late June 2014 by 90 $\mathrm{cm}$ long temperature probe placed at different depths (Digi-Sense Type K Thermometer Probe, Oakton Instruments, IL, USA). Volumetric soil water content in the top $0-5 \mathrm{~cm}$ of soil was measured during campaigns in 2013 to 2016 by a handheld Theta Probe (Model ML3, Delta-T Devices Ltd., Cambridge, England), with a "mineral soil factory calibration curve" that has been found to give realistic results for Icelandic Andosols in S Iceland (Berglind Orradottir, pers. comm.). Soil depth was measured using a $1 \mathrm{~m}$ long metallic rod pushed down until hitting a rock at 11 places along the $\mathrm{S}$ edge of each permanent plot, but recorded as $100 \mathrm{~cm}$ when deeper. A relative measure for exchangeable sulphur (S) was obtained using exchange membranes (PRS ${ }^{\mathrm{TM}}$ probes, Western Ag Innovations Inc., Saskatoon, SK, Canada). The membranes continuously absorb charged ionic species over the burial period, and the $\mathrm{S}$ availability is calculated as soil $\mathrm{S}$ flux over time. Four sets of membranes were inserted at 0-10 cm depth for 89 days (23 May to 20 August 2013) in each permanent plot. Afterwards, they were sent to Western Ag Innovations Inc. (Saskatoon, SK, Canada) for further analyses. Soil $\mathrm{pH}$ in $\mathrm{H}_{2} \mathrm{O}$ and $1 \mathrm{M} \mathrm{KCl}$ was determined from sieved (mesh size $2 \mathrm{~mm}$ ) soil samples taken from $0-10 \mathrm{~cm}$ layers in all permanent plots in July 2014. The samples were dissolved in a 1:2.5 (per mass) solution, shaken for $20 \mathrm{~min}$ and shaken shortly again after two hours before measuring $\mathrm{pH}$ with a Two Channel Benchtop $\mathrm{pH} / \mathrm{mV} / \mathrm{ISE}$ Meter (Hanna Instruments, Temse, Belgium). Finally, the potential decomposition rate of easily decomposable organic matter was determined with the TBI method (Keuskamp et al. 2013). Four Lipton Green teabags were incubated at 5-7 $\mathrm{cm}$ depth in each permanent plot from late May to the middle of September (110 days) in 2014 and then dried at $85{ }^{\circ} \mathrm{C}$ for 48 hours, weighed and their mass loss compared to stored control bags.

\section{Statistical analysis}

Individual permanent study plots in each site type were used as the unit of replication $(n=25$ or 30 , without and with the F treatment plots, respectively), except when standard deviations of all observations were calculated. Then all individual measurements were included. OneWay ANOVA was used to test for differences in mean annual values between the three site types, and when significant followed by Fisher's Least Significant Difference (LSD) pairwise tests (SAS, version 9.4; SAS Institute Inc., Cary, NC, USA). The potential effect of soil warming on different parameters was evaluated with a

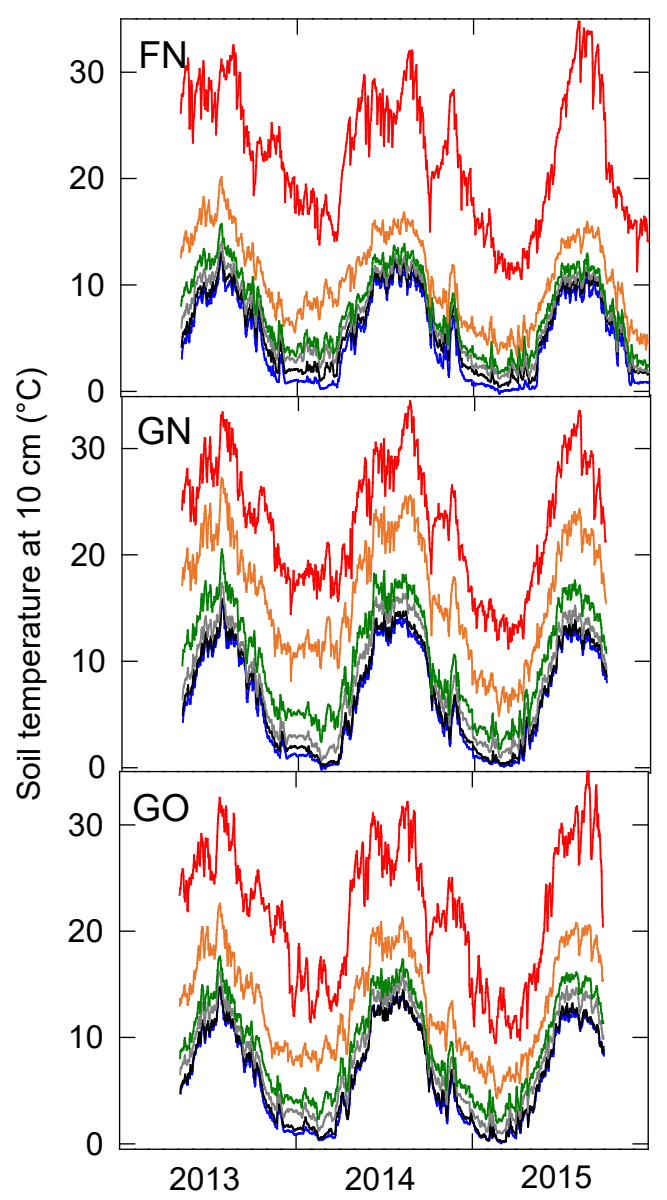

Figure 2. Changes in daily mean soil temperature (Ts) at $10 \mathrm{~cm}$ depth in the six warming levels (A-F) of recently warmed forest (FN; top), grassland (GN; middle) and long-term warmed grassland (GO; bottom). Warming levels are A (unwarmed control; dark blue), B (black), C (grey), D (green), E (orange) and $\mathrm{F}$ (red). For evaluation of warming levels see Table 2. 
Table 2. Mean annual soil temperature at $10 \mathrm{~cm}$ depth (MATs, ${ }^{\circ} \mathrm{C} ; \pm \mathrm{Sd}$ ) and mean annual warming $\left(\mathrm{W},{ }^{\circ} \mathrm{C}\right.$ ) in 2014 and the maximum and minimum hourly warming (Wmin, Wmax ; ${ }^{\circ} \mathrm{C}$ ) relative to average MATs on unwarmed (A) plots and different soil warming levels (B-F). Fraction of hourly MATs data from 2014 within 1, 3,5 and $10^{\circ} \mathrm{C}$ of the annual mean (Variation; $\pm 1, \pm 3, \pm 5$ and $\pm 10^{\circ} \mathrm{C}$ ), July mean Ts in $2013,2014,2015$, and January mean soil temperature (Ts) in 2014 and 2015 of the recently warmed forest (FN), grassland (GN), and long-term warmed grassland (GO). All averages and standard deviations are for $n=5$ plots per warming level (WL).

\begin{tabular}{|c|c|c|c|c|c|c|c|c|c|c|c|c|c|c|}
\hline & \multirow[b]{2}{*}{ WL } & \multicolumn{4}{|c|}{2014} & \multicolumn{4}{|c|}{ Variation (\%) in 2014} & \multicolumn{3}{|c|}{ July Ts } & \multicolumn{2}{|c|}{ January Ts } \\
\hline & & MATs & W & $\mathrm{W}_{\min }$ & $\mathrm{W}_{\max }$ & \pm 1 & \pm 3 & \pm 5 & \pm 10 & 2013 & 2014 & 2015 & 2014 & 2015 \\
\hline \multirow[t]{6}{*}{$\mathrm{FN}$} & A & $5.3 \pm 0.2$ & 0.0 & -0.9 & 1.0 & 99 & 100 & & . & 10.0 & 10.5 & 9.4 & 1.0 & 0.7 \\
\hline & B & $6.2 \pm 0.5$ & 1.0 & -0.2 & 3.3 & 88 & 100 & . & . & 10.6 & 11.0 & 9.9 & 2.0 & 1.6 \\
\hline & $\mathrm{C}$ & $7.2 \pm 0.5$ & 1.9 & 0.2 & 4.3 & 73 & 99 & 100 & 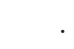 & 11.6 & 11.5 & 10.5 & 3.6 & 2.3 \\
\hline & $\mathrm{D}$ & $8.0 \pm 0.2$ & 2.7 & 0.7 & 5.4 & 73 & 96 & 100 & . & 13.1 & 12.4 & 11.5 & 4.5 & 3.2 \\
\hline & $\mathrm{E}$ & $11.1 \pm 0.7$ & 5.8 & 2.7 & 10.3 & 50 & 86 & 98 & 100 & 17.2 & 15.1 & 14.0 & 7.9 & 5.4 \\
\hline & $\mathrm{F}$ & $22.8 \pm 2.2$ & 17.5 & 9.4 & 25.0 & 25 & 49 & 85 & 99 & 27.8 & 25.7 & 28.3 & 17.8 & 15.7 \\
\hline \multirow[t]{6}{*}{ GN } & A & $6.3 \pm 0.3$ & 0.0 & -1.5 & 1.4 & 95 & 100 & & . & 12.5 & 12.9 & 12.5 & 1.1 & 0.8 \\
\hline & B & $6.8 \pm 0.3$ & 0.5 & -1.4 & 1.9 & 96 & 100 & . & . & 12.9 & 13.5 & 13.0 & 1.7 & 1.2 \\
\hline & $\mathrm{C}$ & $8.3 \pm 1.4$ & 2.1 & -0.2 & 4.1 & 35 & 93 & 100 & . & 14.3 & 15.0 & 14.2 & 2.8 & 2.3 \\
\hline & $\mathrm{D}$ & $10.2 \pm 0.3$ & 3.9 & 0.3 & 7.4 & 49 & 97 & 100 & . & 16.9 & 16.4 & 16.5 & 5.1 & 3.6 \\
\hline & E & $16.7 \pm 2.5$ & 10.5 & 3.7 & 15.0 & 22 & 68 & 97 & 100 & 23.3 & 22.1 & 22.5 & 11.5 & 8.1 \\
\hline & $\mathrm{F}$ & $23.6 \pm 1.3$ & 17.3 & 8.8 & 24.2 & 30 & 75 & 93 & 100 & 29.4 & 28.3 & 30.5 & 18.2 & 14.6 \\
\hline \multirow[t]{6}{*}{ GO } & A & $6.3 \pm 0.6$ & 0.0 & -1.8 & 1.9 & 82 & 99 & 100 & . & 11.8 & 12.9 & 11.9 & 1.1 & 1.1 \\
\hline & B & $6.5 \pm 0.6$ & 0.2 & -1.8 & 2.6 & 77 & 100 & . & . & 12.0 & 12.7 & 12.4 & 1.6 & 1.2 \\
\hline & $\mathrm{C}$ & $7.8 \pm 0.5$ & 1.6 & -0.4 & 3.5 & 74 & 100 & . & . & 13.4 & 14.0 & 13.8 & 3.0 & 2.2 \\
\hline & D & $9.1 \pm 0.3$ & 2.9 & 0.2 & 5.2 & 71 & 100 & . & . & 14.7 & 15.0 & 15.4 & 4.2 & 3.6 \\
\hline & E & $13.0 \pm 2.0$ & 6.8 & 2.7 & 10.4 & 28 & 82 & 99 & 100 & 19.4 & 18.6 & 19.2 & 8.3 & 7.3 \\
\hline & $\mathrm{F}$ & $21.9 \pm 3.3$ & 15.6 & 6.5 & 25.7 & 19 & 53 & 70 & 95 & 27.7 & 26.3 & 28.7 & 15.6 & 14.2 \\
\hline
\end{tabular}

linear regression analysis using mean annual Ts' measured for each plot.

\section{RESULTS}

The mean annual soil temperature (MATs) of the unwarmed soil was $6.3{ }^{\circ} \mathrm{C}$ in the two grasslands, but $5.3{ }^{\circ} \mathrm{C}$ under the dense forest cover in 2014 (Figure 2; Table 2). The July and January Ts' were on average $12.4^{\circ} \mathrm{C}$ and $1.0{ }^{\circ} \mathrm{C}$ in the unwarmed grassland, but $10.0^{\circ} \mathrm{C}$ and 0.9 ${ }^{\circ} \mathrm{C}$ at $\mathrm{FN}$, respectively (Table 2). Frozen soil below $10 \mathrm{~cm}$ depth in winter, indicated with Ts being stable around $0{ }^{\circ} \mathrm{C}$, did occur. While this only lasted for a limited time in the unwarmed grasslands, the unwarmed forest (FN) showed longer periods with frozen soil during winter (Figure 2).

All the warming levels (WLs) were similar during the three years of study and followed the natural Ts seasonal cycle, with relatively stable offset and no periods with frozen soil for the WLs of C to F (Figure 2). We were not successful in placing the permanent plots at exactly the same MATs in each site type, but the average WL across the three site types was $+0.6,+1.9,+3.2,+7.7$ and $+16.8^{\circ} \mathrm{C}$ for $\mathrm{B}, \mathrm{C}$, $\mathrm{D}, \mathrm{E}$ and F, respectively (Table 2). Both natural unwarmed Ts and the WLs fluctuated, but for 
A, B, C and D the hourly mean Ts was more or less always within $\pm 3{ }^{\circ} \mathrm{C}$ of the annual average WL for each site type. The fluctuation became somewhat larger for $\mathrm{E}$ and $\mathrm{F}$, where the hourly mean Ts was within $\pm 3{ }^{\circ} \mathrm{C}$ for $79 \%$ and $59 \%$ of the time across the three site types (Table

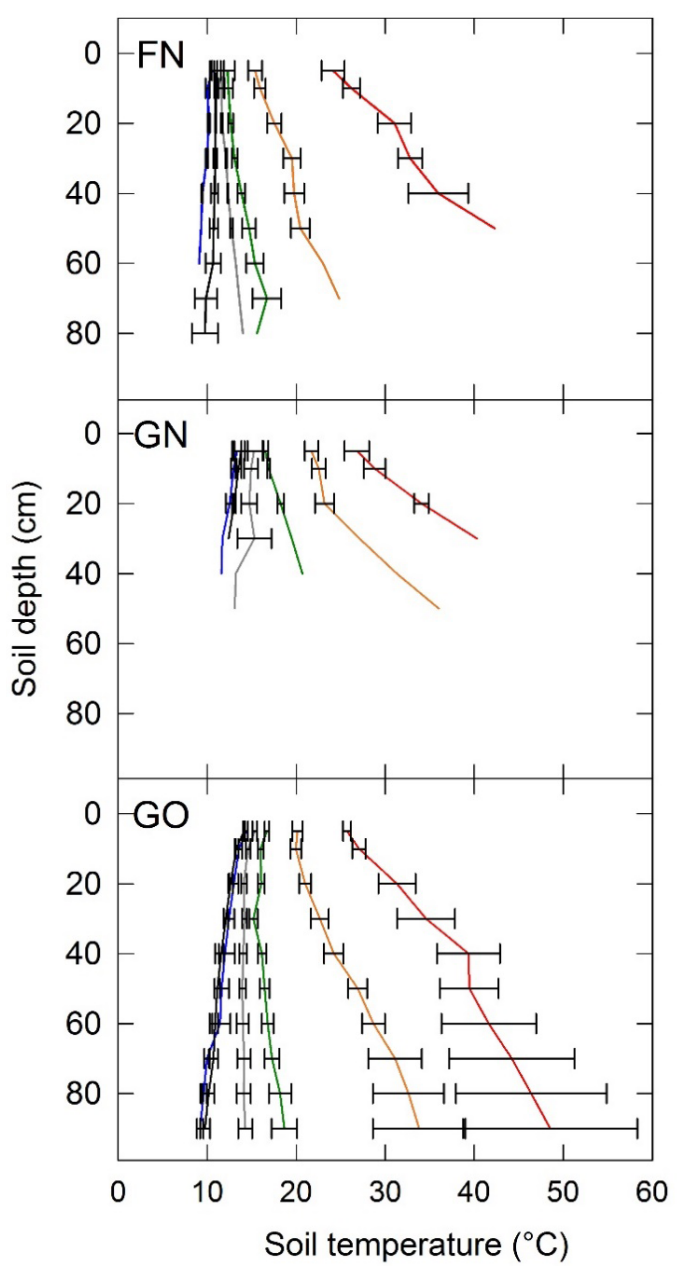

Figure 3. Vertical profiles $(5,10,20, \ldots 90 \mathrm{~cm})$ of soil temperature in the six warming levels (A-F) of the recently warmed forest (FN; top) and grassland (GN; middle) and the long-term warmed grassland (GO; bottom) at 27 June 2014. Vertical lines represent loess fits between measured averages and the warming levels are A (unwarmed control; dark blue), B (black), C (grey), D (green), E (orange) and F (red). SEs of Ts measurements from 2-5 plots are shown as lateral bars.
2). The absolute annual peak values for hourly maximum and minimum warming during 2015 for each WL are also shown in Table 2.

A survey measuring vertical Ts profiles at all WLs at all three site types showed that the Ts measured at $10 \mathrm{~cm}$ depth were relatively constant in all WLs down to ca. 20-25 cm depth, which represents the most active root layer. Only in the warmest level (F; Figure 3), did the Ts increase more rapidly with depth and there the Ts, which were measured at $10 \mathrm{~cm}$ depth, would clearly underestimate the soil warming in the $15-30 \mathrm{~cm}$ layer. The spatial variability among the five replicated plots within each WL increased with Ts (Figure 3), indicating

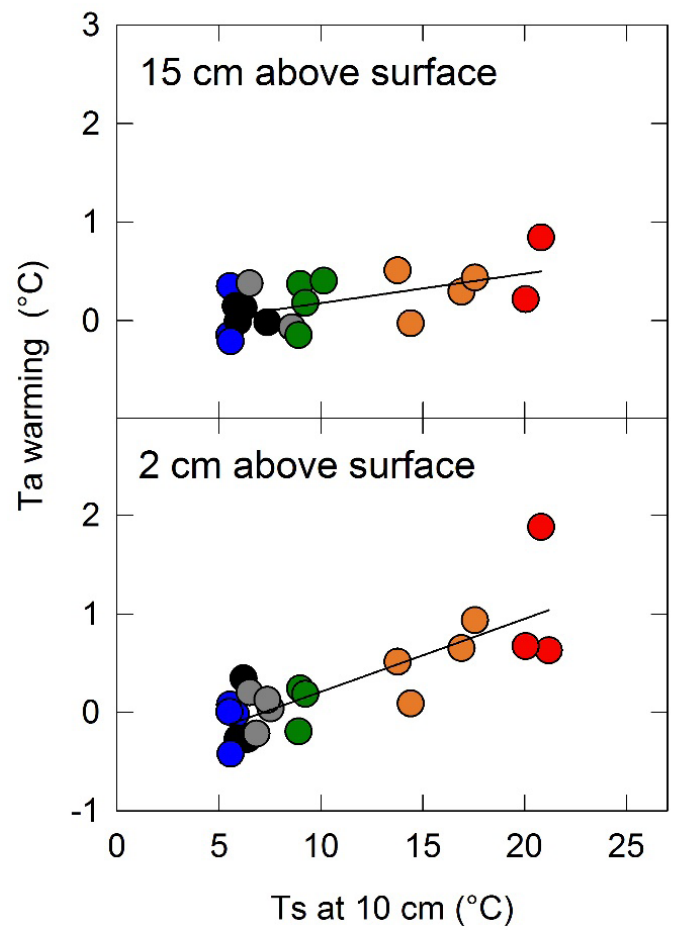

Figure 4. The relationship between mean soil temperature (Ts) at $10 \mathrm{~cm}$ depth and average air temperature (Ta) warming compared to Ta measured at $2 \mathrm{~m}$ height for the period 15 February to 30 June 2015 in the ForHot grasslands. Warming levels are A (unwarmed control; dark blue), B (black), C (grey), D (green), E (orange) and $\mathrm{F}$ (red). The lines represent significant regression relationships. 
that it became increasingly difficult to place all plots on exactly similar Ts' as the geothermal warming gradients became steeper. Figure 3 illustrates the differences in soil depth between the three site types, where GN had significantly shallower soils than both GO and FN, and GO had significantly the deepest soils (Table 3).
Within each site type there was, however, no systematic difference in soil depth across the WLs (Table 3; regressions not significant).

Measurements of air temperature (Ta) at 2 $\mathrm{m}$ height at different places in FN showed no effects of the soil warming (data not shown) and therefore $\mathrm{Ta}$ at $2 \mathrm{~m}$ was only measured at one

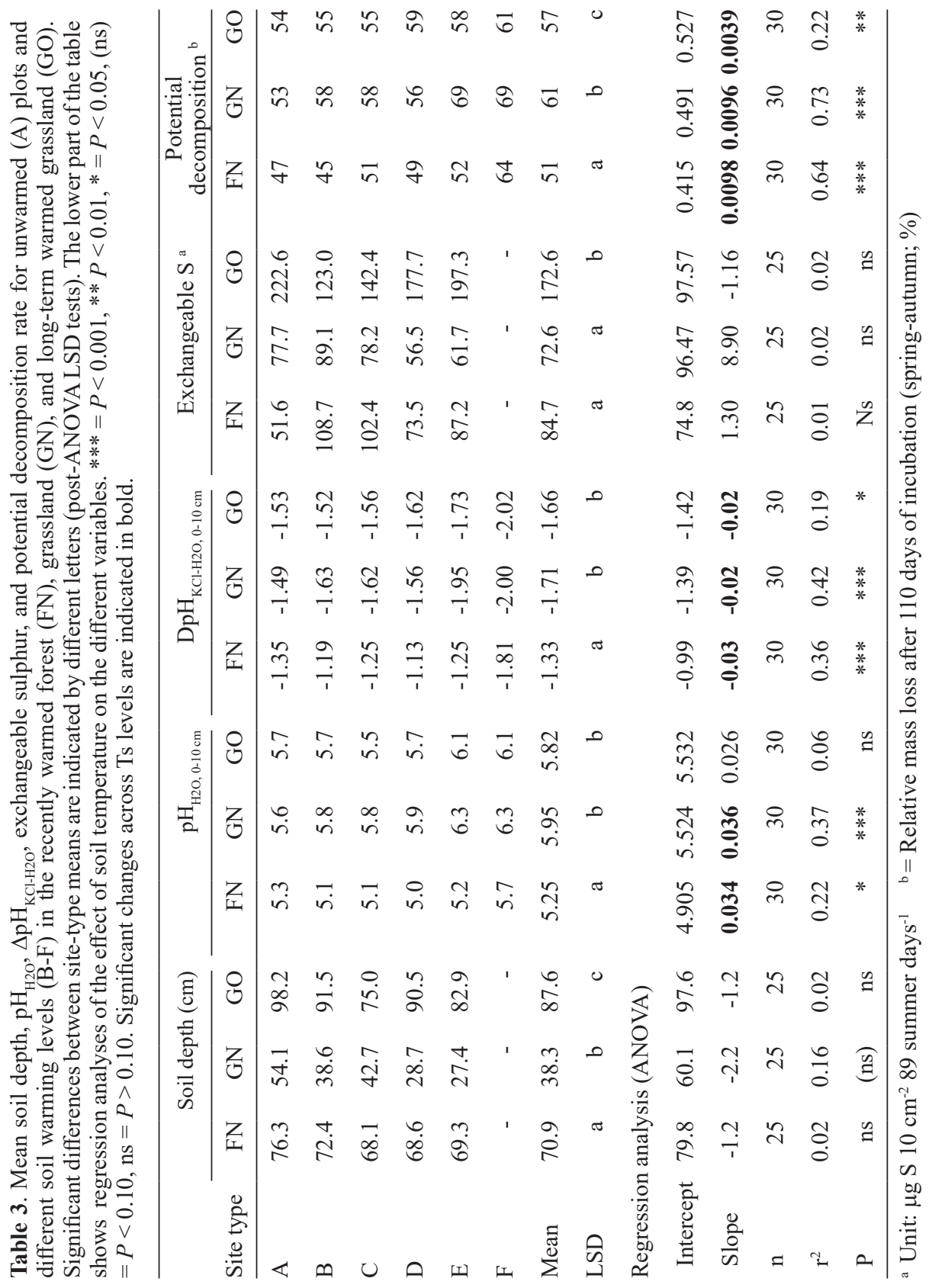


location in GN and GO. At 2 and $15 \mathrm{~cm}$ height above the surface in GN and GO the regression relationships between average Ts $\left({ }^{\circ} \mathrm{C}\right)$ and average Ta warming $\left(\Delta \mathrm{Ta} ;{ }^{\circ} \mathrm{C}\right)$ were significant (Figure $4 ; \Delta \mathrm{Ta}_{15}: \mathrm{r}^{2}=0.32 ; \mathrm{P}=0.01 ; \Delta \mathrm{Ta}_{02}: \mathrm{r}^{2}=$ $0.65 ; \mathrm{P}<0.001)$ :

$\Delta \mathrm{Ta}_{15}=0.03 \times \mathrm{Ts}-0.12$,

$\Delta \mathrm{Ta}_{02}=0.07 \times \mathrm{Ts}-0.53$.

The above relationships indicate that air warming was substantially less than the soil warming, and a $20{ }^{\circ} \mathrm{C}$ increase in Ts only elevated the average Ta by $0.95{ }^{\circ} \mathrm{C}$ and 0.48 ${ }^{\circ} \mathrm{C}$ at $2 \mathrm{~cm}$ and $15 \mathrm{~cm}$ height above the surface, respectively (Figure 4).

Measurements of $\mathrm{pH}_{\mathrm{H} 2 \mathrm{O}}$ of the top $10 \mathrm{~cm}$ of mineral soil did not show any indications that geothermal water had reached the root zone in any of the sites (Table 3 ). In the unwarmed soil, the $\mathrm{pH}$ was significantly lower in the coniferous forest plantation than in the two grasslands, which did not differ (pH 5.2 in FN vs. ca. 5.9 in GN and GO). Soil pH did, however, increase somewhat with $\mathrm{Ts}$ and this change was significant in the recently warmed sites (FN and $\mathrm{GN})$, but not in the long-term warmed site (GO). $\Delta \mathrm{pH}_{\mathrm{KCl}-\mathrm{H} 2 \mathrm{O}}$, which was also significantly lower in FN than in the two grasslands, increased significantly with WL in all three site types (Table 3). A lack of geothermal contamination was further supported by the lack of significant regressions between $\mathrm{Ts}$ and exchangeable sulphur (S) in the soil in any of the site types (Table 3). The overall level of exchangeable $\mathrm{S}$ was, however, higher in GO, where a higher number of geothermal vents were found within the same valley than in the recently warmed sites.

All site types had the highest volumetric water content (WC) early in the spring and the lowest measured surface WCs in the middle of summer (Figure 5). The average surface WCs of the unwarmed control treatments $\left(\mathrm{WC}_{\text {meanA }}\right)$ during the period of 11 April to 1 September 2016 were $52.2 \%, 38.8 \%$ and $31.1 \%$ in GO, GN and FN, respectively (Figure 5), and similar values were obtained in 2013-2015 (Table 4). When

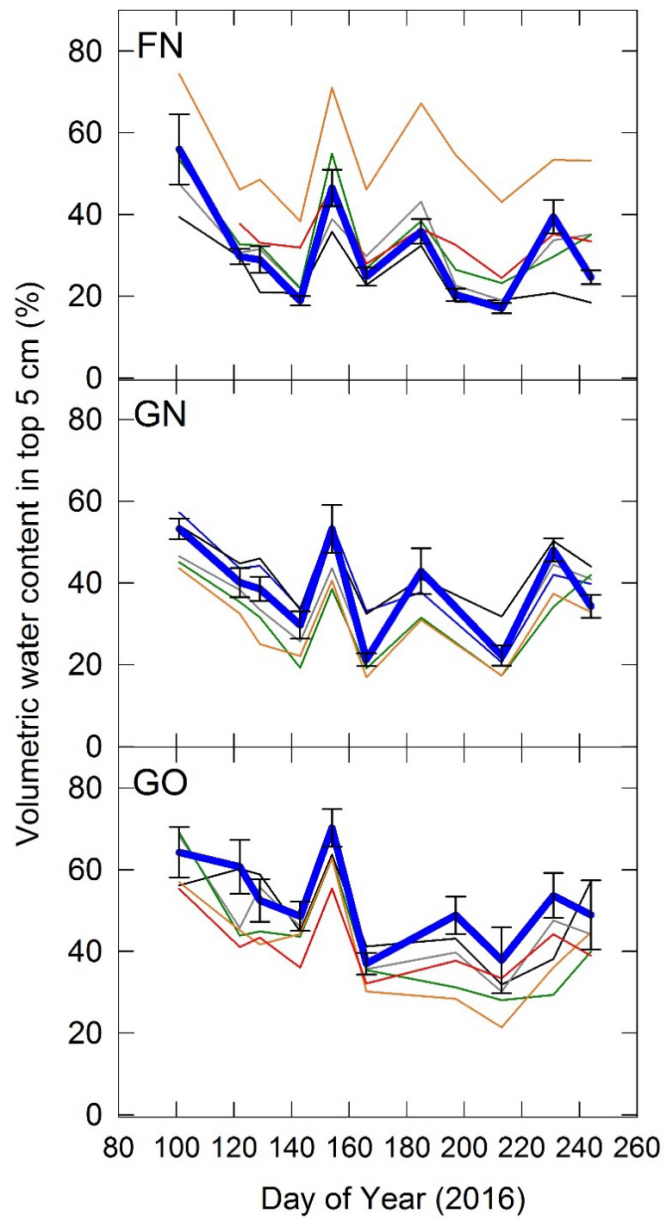

Figure 5. Changes in mean volumetric water content (WC) in the top $5 \mathrm{~cm}$ in the six warming levels (A-F) of the recently warmed forest (FN; top) and grassland (GN; middle) and the long-term warmed grassland (GO; bottom) from April to August 2016. Warming levels are A (unwarmed control; dark blue, thicker line, including SE of the mean), B (black), C (grey), $\mathrm{D}$ (green), E (orange) and F (red).

the plot-level WCs for individual measurement days were compared across the soil warming gradients in each site type, a significant linear drying effect with warming was observed for the surface soil for a part of the dates in both GN and GO, but only a few times in FN, which was the driest site (regression analysis; data not shown). 
Table 4. Mean volumetric soil water content (\%) in the top $5 \mathrm{~cm}$ in unwarmed soil (WCmeanA) and across all soil temperature (Ts) levels (WCmean) and the corresponding standard deviation (WCSd) in 2013 to 2016 in the recently warmed forest (FN), grassland (GN), and long-term warmed grassland (GO). The lower part of the table shows regression analyses of the effect of mean soil temperature on the mean seasonal plot-wise WC. Int. $=$ intercept, Sl. $=$ slope. ${ }^{* * *}=\mathrm{P}<0.001,{ }^{*} \mathrm{P}<0.01, *=\mathrm{P}<0.05$, (ns) $=\mathrm{P}<0.10$, ns $=\mathrm{P}>0.10$. Significant seasonal increases or reductions in WC with Ts are indicated in bold.

\begin{tabular}{|c|c|c|c|c|c|c|c|c|c|c|c|c|}
\hline \multirow[b]{2}{*}{ Site type } & \multicolumn{3}{|c|}{2013} & \multicolumn{3}{|c|}{2014} & \multicolumn{3}{|c|}{2015} & \multicolumn{3}{|c|}{2016} \\
\hline & FN & GN & GO & FN & GN & GO & FN & GN & GO & $\mathrm{FN}$ & GN & GO \\
\hline Campaigns & 4 & 4 & 4 & 12 & 8 & 8 & 4 & 6 & 6 & 11 & 10 & 10 \\
\hline $\mathrm{WC}_{\text {mean }} \mathrm{A}(\%)$ & 31.2 & 38.3 & 36.4 & 33.3 & 49.4 & 53.5 & 28.6 & 46.4 & 54.0 & 31.1 & 38.4 & 52.3 \\
\hline $\mathrm{WC}_{\text {mean }}(\%)$ & 33.9 & 36.6 & 33.9 & 44.4 & 47.9 & 52.1 & 37.5 & 42.4 & 51.5 & 35.5 & 36.6 & 46.0 \\
\hline $\mathrm{WC}_{\mathrm{Sd}}(\%)$ & 9.0 & 7.3 & 9.0 & 15.3 & 13.7 & 14.1 & 15.6 & 13.5 & 14.9 & 15.9 & 13.6 & 15.7 \\
\hline \multicolumn{13}{|c|}{ Regression analysis (ANOVA) } \\
\hline Int. (\%) & 15.25 & 43.8 & 37.89 & 39.4 & 56.7 & 60.0 & 30.6 & 51.6 & 58.4 & 31.8 & 44.9 & 52.0 \\
\hline S1. $\left(\%{ }^{\circ} \mathrm{C}^{-1}\right)$ & +2.46 & -0.75 & -0.20 & +0.50 & -0.74 & -0.73 & +0.68 & -0.77 & -0.65 & +0.33 & -0.71 & -0.56 \\
\hline $\mathrm{n}$ & 25 & 25 & 25 & 30 & 30 & 30 & 30 & 30 & 30 & 30 & 30 & 30 \\
\hline $\mathrm{r}^{2}$ & 0.61 & 0.40 & 0.02 & 0.10 & 0.44 & 0.22 & 0.12 & 0.57 & 0.24 & 0.03 & 0.37 & 0.15 \\
\hline $\mathrm{P}$ & $* * *$ & $* * *$ & ns & (ns) & $* * *$ & $* *$ & (ns) & $* * *$ & $* *$ & $\mathrm{~ns}$ & $* * *$ & * \\
\hline
\end{tabular}

During 2013-2016, the surface WC did not change significantly (2014-2016) or it was even significantly increased with increasing Ts (2013) in $\mathrm{FN}$, when averaged over the whole growing season (ranging between +0.33 to $+2.46 \% \mathrm{WC}$ ${ }^{\circ} \mathrm{C}^{-1}$; Table 4). The increase in $\mathrm{WC}$ at $\mathrm{FN}$ was especially pronounced at warming level E. In GN, however, the seasonal mean surface WC was always significantly reduced across the Ts gradients $\left(-0.71\right.$ to $\left.-0.77 \% \mathrm{WC}{ }^{\circ} \mathrm{C}^{-1}\right)$, while in $\mathrm{GO}$ it shifted between no significant change to significantly reduced $\left(-0.20\right.$ to $-0.73 \% \mathrm{WC}^{\circ} \mathrm{C}^{-1}$; Figure 5; Table 4). It should, however, be noted that the observed surface WCs in the warmest treatments of GO were still substantially higher than the unwarmed control FN soil (e.g. $41.8 \%$ vs. $31.1 \% \mathrm{WC}$ in 2016). The warmest GN plots were usually similar to the unwarmed $\mathrm{FN}$ soil, on average (30.0\% vs. $31.1 \% \mathrm{WC}$, respectively, in 2016; Figure 5).

To indicate how ecosystem processes responded to the soil warming, the potential decomposition rate of organic matter is shown (Table 3). Green tea decomposed faster in the two grasslands than in the forest site in unwarmed soil. The soil warming, significantly increased the decomposition rate in all three site types, but to a different degree. The slope of the temperature response was almost identical for the two recently warmed sites (FN and GN), but it was ca. $60 \%$ lower in the long-term warmed grassland. The net result was therefore that the observed mean decomposition potential across all WLs was significantly highest in GN, second in GO, and significantly lowest in FN (Table 3).

\section{DISCUSSION}

\section{Realism of the soil warming}

The main concern when starting the ForHot project was whether geothermal water, which is rich in various dissolved minerals, reached the rooting zone in the soils and thus created difficult conditions for many organisms (Wetang'ula \& Snorrason 2005). If this was the case, observed changes in processes and ecosystem structure might have been driven by chemical factors rather than by temperature changes. Our results for $\mathrm{pH}$ and exchangeable $\mathrm{S}$ showed no indication of contamination by geothermal water in any of the ForHot sites. The lack of contamination was further confirmed in a recent thesis on seasonal soil water chemistry below the root zone at the 
FN site (Edlinger 2016). A second concern was that the natural seasonal patterns of Ts would flatten out at the warmed plots. This was not the case, as can clearly be seen in Figure 2. Lastly, we also expected the vertical Ts gradients in geothermally affected plots to become very different from the ones in unwarmed conditions, i.e. that Ts would increase dramatically with soil depth. The difference was, however, marginal (except for the warmest $\mathrm{F}$ plots), especially for the top $20-30 \mathrm{~cm}$ of soil containing most of plant roots.

All the above findings support the hypothesis that the ForHot project geothermal gradients offer conditions similar to, for example, manipulation studies with soil heating cables for studying the effects of soil warming (Rustad 2001, Strömgren \& Linder 2002, Bronson \& Gower 2010, Patil et al. 2013, Streit et al. 2013, Krassovski et al. 2015, Schindlbacher et al. 2015).

\section{Stability of the soil warming}

It is neither expensive nor difficult to maintain the soil warming in the ForHot sites, but since the warming is entirely passive it cannot be controlled. During the study period of 20132015 the geothermal gradients remained relatively stable at all three sites. Geothermal systems, however, tend to be dynamic in nature (Carotenuto et al. 2016), as was also witnessed in the present study by the creation of the new geothermal gradients during the large 2008 earthquake (Porbjörnsson et al. 2009). This complicates the estimation of the duration of unchanged warming in Grændalur (GO). Based on the survey in autumn 2008 by Porbjörnsson et al. (2009), showing little change in distribution of hotspots and geothermal vents in those areas (especially for transects 1-4 of GO), and Kristjánsson's first mapping of the geothermal hotspots in the same area during 1963-1965, it was assumed that they have existed for at least 50 years. However, even though Grændalur has had these geothermal hot spots for centuries, they may have changed both spatially and thermally over time. To further study the temporal and spatial history of the geothermal warming at
GO, there is an ongoing activity using HPLC (High Performance Liquid Chromatography) analysis to study recalcitrant soil bacteria lipids in soil profiles from GO, which may be used to reconstruct historical soil temperature (De Jonge, pers. comm.). Such measurements have been successfully used as paleo-climate proxies of soil temperature elsewhere (De Jonge et al. 2014).

\section{Warming-induced drying}

A general concern with all terrestrial warming experiments is their effect on soil and plant water status, since their warming treatments will inevitably increase evapotranspiration and therefore potentially induce drought, which could confound the "warming responses" (Lu et al. 2012, De Boeck et al. 2015). Whether such drying will induce some strong biological or biogeochemical responses depends largely on the hydrological conditions of each site. The annual precipitation tends to be high at Reykir (between 1134 and $2023 \mathrm{~mm}$ in 1972-2000; Icelandic Meteorological Office, 2016) and due to the relatively short summer and the high water storage capacity of the sites' soil type (Arnalds 2015), drought was not expected to be a major driver at the ForHot sites.

The driest surface soils were in the FN forest, where the dense forest stand likely had both higher transpiration and much higher evaporation from intercepted rainfall than the grasslands (cf. Koivusalo et al. 2006). However, no signs of water stress were observed when the stomatal conductance of the Sitka spruce trees was measured (André \& Bondesson 2014). Further, no significant drying was observed at higher WLs in FN. On the contrary, there was a strong "wetting", especially at ca. +10 ${ }^{\circ} \mathrm{C}$ soil warming. This occurred exactly at the interface where warming-induced tree mortality was taking place (O’Gorman et al. 2014), and where the stand had thinned, but where only a little ground vegetation had colonized (Gudmundsdottir et al. 2014, Cilio 2014). At the F plots, all Sitka spruce trees had died and the ground was covered with lush herbaceous vegetation (Gudmundsdottir et al. 2014). We 
interpret this wetting as a relatively higher reduction in tree transpiration and intercepted rainfall in the warmest treatments in FN compared to the warming-induced drying.

The grasslands did, however, show a significant over-all drying of the surface layer with warming in most years, especially GN, which had thinner soils and therefore less water storage potential. This drying was not always significant and apparently became stronger during and just after the infrequent dry spells in mid- to late summer, when the water content of the unwarmed control plots was also reduced. Such drying of surface soil, however, may not necessarily cause physiological stress for plants, especially not those that have roots that extend below $5 \mathrm{~cm}$. In fact, the soil water status of the "driest" treatments in the grasslands was still similar to the unwarmed control plots in FN. Further, when stomatal conductance $(g s)$ was measured for Ranunculus acris, Poa pratensis and Agrostis capillaris in GO and GN, no significant (drought-induced) stomatal closure was observed across the WLs (Michielsen 2014). The more shallow-rooted Poa and Agrostis grasses had, however, on average significantly lower $g s$ in GN than in GO, which fits well with our measurements of surface water content.

\section{Soil warming vs. air warming}

All soil warming techniques have only limited effects on air temperature (Lu et al. 2012, Streit et al. 2013). Patil et al. (2013) observed only $0.20{ }^{\circ} \mathrm{C}$ warming at $10 \mathrm{~cm}$ height above the soil surface in an experiment where Ts was elevated by $5.0{ }^{\circ} \mathrm{C}$ in agricultural soils by buried heating cables at $10 \mathrm{~cm}$ depth. By applying Eq. 1 we found that the average air warming at $15 \mathrm{~cm}$ height was very similar in our case where the Ts was exactly $5^{\circ} \mathrm{C}$ warmer, or $0.15^{\circ} \mathrm{C}$ warmer. The surface air warming was stronger, but still it was an order of magnitude smaller than the warming at $10 \mathrm{~cm}$ soil depth. This calls for some caution when findings of aboveground processes measured in soil-warming experiments are extrapolated in relation to future climate warming. An example is the effect of warming on tree canopy gas exchange which was measured at ca. $8 \mathrm{~m}$ height above the soil surface (André \& Bondesson 2014). There the effects of the soil warming are interesting in terms of better understanding the potential effects soil and root temperatures can have on such aboveground processes, but it is highly doubtful that the responses could be used to predict photosynthesis or transpiration of spruce in a future climate. This is a general issue with soil warming experiments, and ForHot is neither better nor worse in that respect than other recent or ongoing soil warming manipulation studies (Patil et al. 2013, Streit et al. 2013).

\section{Effects on potential decomposition}

At higher latitudes $\left(>60{ }^{\circ} \mathrm{N}\right)$, soils store the largest part of the total ecosystem organic matter (Scharlemann et al. 2014). This is also the case for the Andosols of Iceland (Arnalds 2015). Understanding the dynamics of organic matter (C) pools, including turnover of litter (Davidson \& Janssens 2006), roots (Leppälammi-Kujansuu et al. 2014) and biota in soil (Clemmensen et al. 2013) is therefore key to making sound predictions of future ecosystem $\mathrm{C}$ balance under changing climatic conditions. In this paper, which has mainly focused on methodological issues, we only show warming effects on one such process; the potential decomposition rate of easily decomposable organic material. As expected, the potential decomposition rate was significantly enhanced with increasing Ts in all three site types. Interestingly, however, the slope of the temperature response was much lower in GO, than in GN and FN. This might indicate some acclimation in the GO grasslands in terms of the rate of organic matter breakdown. A recent review of Lu et al. (2012) found indications that the temperature sensitivity of microbes declines at higher temperature levels in manipulation experiments or that the microbes themselves may acclimatize to high temperatures. Further studies on the different aspects of the C-cycle of the ForHot grassland sites are being conducted (Leblans 2016, Poeplau et al. 2016). 


\section{Other observed effects of warming}

The soil $\mathrm{pH}_{\mathrm{H} 2 \mathrm{O}}$ increased slightly, but significantly so, with warming in both GN and $\mathrm{FN}$, but not in GO. This might have been driven by a decrease in vascular plant root-litter inputs at the higher temperatures (Way \& Oren 2010) and/or a gradual depletion of partly decomposed humic materials in the warmer soils of FN and GN after the warming was initiated in 2008. The reverse process, i.e. a gradual decrease of $\mathrm{pH}_{\mathrm{H} 2 \mathrm{O}}$ as vegetation cover or productivity increases, is well known in Icelandic grassland and forest soils (Sigurðsson et al. 2005, Sigurdsson \& Magnusson 2010, Vilmundardottir et al. 2015).

Another interesting finding was the gradually increased $\Delta \mathrm{pH}_{\mathrm{KCl}-\mathrm{H} 2 \mathrm{O}}$ with warming in all three site types. This so-called "reserve acidity" is generally caused by additional $\mathrm{Al}^{3+}$ and $\mathrm{H}^{+}$being released from exchange sites in the soil (Arnalds 2015). This increase may therefore indicate certain soil structural change due to warming, which increased the amount of such exchange sites being exposed. Indeed, a warming-induced change in soil structure and breakdown of soil aggregates has recently been found to be an important driver for the observed alterations in soil organic matter at GN, apart from the increasing decomposition potential caused by higher temperatures (Poeplau et al. 2016). This is a very interesting finding and may change our understanding of how climate change is likely to affect soil organic matter.

\section{CONCLUSIONS}

We conclude that the large natural geothermal gradients at the ForHot sites in Iceland have offered realistic conditions to study terrestrial ecosystem responses to warming with minimal artefacts. This conclusion was supported by the findings that the soil warming was relatively stable over multiple years and the seasonal patterns of Ts in the warmed plots closely followed the unwarmed plots. In this respect the geothermal warming simulated the natural conditions better than expected. Also, it was found that, even if other potential environmental drivers such as surface soil water content and soil $\mathrm{pH}$ were not insensitive to the warming, their changes were relatively mild and should not have overridden the direct warming effects on biological processes.

A certain caution must, however, be used when findings from such geothermal gradients are interpreted in relation to the possible largescale effects of future climate warming: i) Such gradients are only found in the volcanic areas of the world and various soil and ecosystem conditions there may differ from other areas. ii) Since geothermal gradients mainly warm the belowground parts of the ecosystem, they may underrepresent responses in aboveground processes that are more controlled by air temperature. iii) The stepwise increase in soil temperature at the initiation of a geothermal gradient may cause some differences in shortterm responses to warming compared to gradual climate warming. The last two issues are also a general problem with all ongoing soil warming manipulation experiments.

\section{ACKNOWLEDGEMENTS}

This work has been supported by a project grant from the Icelandic Research Council (Rannsóknasjóður, ForHot-Forest, Project No 163272-051), a FWO PhD grant from the Research Foundation - Flanders (Grant No $11 \mathrm{G} 1615 \mathrm{~N})$, a European Research Council Synergy grant (IMBALANCE-P, Project No 610028), and a Research Council of the University of Antwerp grant (FORHOT TOPBOF project). This work contributes also to the SNS funded Nordic CAR-ES III project and the ClimMani COST Action (ES1308). The Agricultural University of Iceland and Icelandic Forest Research provided logistical support. We thank the Lorentz Center, Leiden, NL, for a workshop grant in 2014. Sigmundur H. Brink made the map in Fig. 1. We also thank all students, fellow researchers and technicians who have taken part in the work presented here; especially Agnes Bondesson, Alexander Meire, Armando Lenz, Ásrún Elmarsdóttir, Baldur Vigfússon, Björn Traustason, Brita Berglund, Brynhildur Bjarnadóttir, Brynja Hrafnkelsdóttir, 
Börkur H. Bl. Hrafnkelsson, Dajana Radujkovic, Damiano Cilio, Elías Óskarsson, Ella Thoen, Freja Dreesen, Hanna André, Helena M. Stefánsdóttir, Katherine Vande Velde, Lieven Michielsen, Már Gudmundsson, Nadine Calluy, Sebastien Leys, Sighvatur Björgvinsson, Símon Arnar Pálsson, Snorri Porsteinsson, Stephanie Van Loock, Úlfur Óskarsson and Wendelien Meynzer.

\section{REFERENCES}

André H \& Bondesson A 2014. Hur en ökad marktemperatur påverkar fotosyntes och markrespiration i en boreal skog [How increased soil temperature affects photosynthesis and soil respiration in a boreal forest]. M.Sc. thesis. Swedish University of Agricultural Sciences, Uppsala, Sweden, 51 p [in Swedish].

Arnalds 0 2015. The Soils of Iceland. Springer, Dordrecht, Heidelberg, New York, London, 183 p.

Bergh J, Freeman M, Sigurdsson BD, Kellomäki S, Laitinen K, Niinistö S, Peltola $H$ \& Linder S 2003. Modelling the short-term effects of climate change on the productivity of selected tree species in Nordic countries. Forest Ecology and Management 183, 327-340. http://dx.doi.org/10.1016/S0378-1127(03)00117-8

Bronson DR \& Gower ST 2010. Ecosystem warming does not affect photosynthesis or aboveground autotrophic respiration for boreal black spruce. Tree Physiology 30, 441-449.

http://dx.doi.org/10.1093/treephys/tpq001

CAFF 2013. Arctic Biodiversity Assessment. Status and trends in Arctic biodiversity. Conservation of Arctic Flora and Fauna (CAFF), Akureyri. Iceland, $674 \mathrm{p}$.

Carotenuto A, Ciccolella M, Massarotti N \& Mauro A 2016. Models for thermo-fluid dynamic phenomena in low enthalpy geothermal energy systems: A review. Renewable and Sustainable Energy Reviews 60, 330-355.

http://dx.doi.org/10.1016/j.rser.2016.01.096

Cilio D 2014. Influenza di un gradiente geotermico di recente comparsa su un imboschimento di Picea sitchensis. Il singolare caso di Reykir, Islanda. B.Sc. thesis. University of Florence, Italy [in Italian].
Clemmensen KE, Bahr A, Ovaskainen O, Dahlberg A, Ekblad A, Wallander H, Stenlid J, Finlay RD, Wardle DA \& Lindahl BD 2013. Roots and associated fungi drive long-term carbon sequestration in Boreal forest. Science 339, 16151618.

http://dx.doi.org/10.1126/science.1231923

Daebeler A, Bodelier PLE, Yan Z, Hefting MM, Jia Z \& Laanbroek HJ 2014. Interactions between Thaumarchaea, Nitrospira and methanotrophs modulate autotrophic nitrification in volcanic grassland soil. ISME Journal 8, 2397-2410.

http://dx.doi.org/10.1038/ismej.2014.81

Daebeler A, Bodelier PLE, Hefting MM \& Laanbroek HJ 2015. Ammonia-limited conditions cause of Thaumarchaeal dominance in volcanic grassland soil. FEMS Microbiology Ecology 91, http://dx.doi.org/10.1093/femsec/fiv014

Davidson EA, Janssens IA \& Luo Y 2006. On the variability of respiration in terrestrial ecosystems: Moving beyond Q10. Global Change Biology 12, 154-164.

http://dx.doi.org/10.1111/j.1365-2486.2005.01065.x

De Boeck HJ, Vicca S, Roy J, Nijs I, Milcu A, Kreyling J, Jentsch A, Chabbi A, Campioli M, Callaghan T, Beierkuhnlein C \& Beier C 2015. Global change experiments: Challenges and opportunities. Bioscience 65, 922-931.

http://dx.doi.org/10.1093/biosci/biv099

De Jonge C, Hopmans EC, Zell CI, Kim J-H, Schouten S \& Sinninghe Damsté JS 2014. Occurrence and abundance of 6-methyl branched glycerol dialkyl glycerol tetraethers in soils: Implications for palaeoclimate reconstruction. Geochimica et Cosmochimica Acta 141, 97-112. http://dx.doi.org/10.1016/j.gca.2014.06.013

Edlinger AT 2016. Changes of belowground processes of the carbon and nitrogen cycle in response to soil warming. Will global warming increase the turnover of soil $C$ and $N$ above plant demands and lead to increased leaching losses? M.Sc. thesis. Copenhagen University, Denmark \& University of Natural Resources and Applied Sciences (BOKU), Austria, Copenhagen, Denmark, 66 p.

Elmarsdottir A, Ingimarsdottir M, Hansen I, Olafsson JS \& Olafsson E 2003. Vegetation and invertebrates in three geothermal areas in Iceland. 
In: Proceedings from International Geothermal Conference, Reykjavik. pp 49-55.

Guðmundsdóttir E, Óskarsson Ú \& Elmarsdóttir Á 2014. Áhrif af hlýnun jarðvegs á gróðurfar í skóglendi og graslendi á Reykjum, Ölfusi [Effects of geothermal warming on forest and grassland flora]. Rit Mógilsár 31, 73-80 [In Icelandic].

Halldórsson B \& Sigbjörnsson R 2009. The Ölfus earthquake at 15:45 UTC on 29 May 2008 in South Iceland: ICEARRAY strong-motion recordings. Soil Dynamics and Earthquake Engineering 29, 1073-1083.

http://dx.doi.org/10.1016/j.soildyn.2008.12.006

Hyvönen R, Ågren GI, Linder S, Persson T, Cotrufo MF, Ekblad A, Freeman M, Grelle A, Janssens IA, Jarvis PG, Kellomäki S, Lindroth A, Loustau D, Lundmark T, Norby RJ, Oren R, Pilegaard K, Ryan MG, Sigurdsson BD, Strömgren M, van Oijen M \& Wallin G 2007. The likely impact of elevated $\left[\mathrm{CO}_{2}\right]$, nitrogen deposition, increased temperature and management on carbon sequestration in temperate and boreal forest ecosystems: a literature review. New Phytologist 171, 275-296.

http://dx.doi.org/10.1111/j.1469-8137.2007.01967.x

Icelandic Meteorological Office 2016. Climate archives for weather stations. Downloaded on Sep 102016 from http://www.vedur.is/vedur/vedurfar/ medaltalstoflur/

IPCC 2013. Climate Change 2013: The Physical Science Basis. Contribution of Working Group I to the Fifth Assessment Report of the Intergovernmental Panel on Climate Change. Stocker TF, Qin D, Plattner G-K, Tignor M, Allen SK, Boschung J, Nauels A, Xia Y, Bex V \& Midgley PM (eds.). Cambridge University Press. Cambridge, UK \& New York, USA, 1535 p.

IUSS Working Group WRB 2015. World Reference Base for Soil Resources 2014, update 2015. International soil classification system for naming soils and creating legends for soil maps. World Soil Resources Reports No. 106. FAO, Rome. 192 p.

Jónsdóttir IS, Magnússon B, Gudmundsson J, Elmarsdóttir Á \& Hjartarson H 2005. Variable sensitivity of plant communities in Iceland to experimental warming. Global Change Biology 11, 553-563.

http://dx.doi.org/10.1111/j.1365-2486.2005.00928.x
Kayler ZE, De Boeck HJ, Fatichi S, Grünzweig JM, Merbold L, Beier C, McDowell N \& Dukes JS 2015. Experiments to confront the environmental extremes of climate change. Frontiers in Ecology and the Environment 13, 219-225.

http://dx.doi.org/10.1890/140174

Keuskamp JA, Dingemans BJJ, Lehtinen T, Sarneel JM \& Hefting MM 2013. Tea Bag Index: A novel approach to collect uniform decomposition data across ecosystems. Methods in Ecology and Evolution 4, 1070-1075.

http://dx.doi.org/10.1111/2041-210X.12097

Koivusalo H, Kokkonen T, Laurén A, Ahtiainen M, Karvonen T, Mannerkoski H, Penttinen S, Seuna P, Starr M \& Finér L 2006. Parametersation and application of a hillslope hydrological model to assess impacts of a forest clear-cutting on runoff generation. Environmental Modelling \& Software 21, 1324-1339.

http://dx.doi.org/10.1016/j.envsoft.2005.04.020

Leblans NIW 2016. Natural gradients in temperature and nitrogen: Iceland represents a unique environment to clarify long-term global change effects on carbon dynamics. Joint Ph.D. thesis at the Agricultural University of Iceland and University of Antwerp, Reykjavik, Iceland, 229 .

Leppälammi-Kujansuu J, Salemaa M, Kleja D, Linder S \& Helmisaari H-S 2014. Fine root turnover and litter production of Norway spruce in a long-term temperature and nutrient manipulation experiment. Plant and Soil 374, 73-88. http://dx.doi.org/10.1007/s11104-013-1853-3

Lu M, Zhou X, Yang Q, Li H, Luo Y, Fang C, Chen J, Yang X \& Li B 2012. Responses of ecosystem carbon cycle to experimental warming: A metaanalysis. Ecology 94, 726-738.

http://dx.doi.org/10.1890/12-0279.1

McGuire AD, Anderson LG, Christensen TR, Dallimore S, Guo LD, Hayes DJ, Heimann M, Lorenson TD, Macdonald RW \& Roulet N. 2009. Sensitivity of the carbon cycle in the Arctic to climate change. Ecological Monographs 79, 523-555.

http://dx.doi.org/10.1890/08-2025.1

Magnússon Á \& Vídalín P 1918-1921. Jarðabók. Annað bindi [The Farm Register of Iceland. 2nd Volume], Copenhagen (Originally published in 1708) [In Icelandic]. 
Michielsen L 2014. Plant communities and global change: adaptation by changes in present species composition or adaptation in plant traits. A case study in Iceland. M.Sc. thesis. University of Antwerp, Antwerp, Belgium. 53 p.

O'Gorman E, Benstead JP, Cross WF, Friberg N, Hood JM, Johnson PW, Sigurdsson BD \& Woodward G 2014. Climate change and geothermal ecosystems: Natural laboratories, sentinel systems, and future refugia. Global Change Biology 20, 3291-3299.

http://dx.doi.org/10.1111/gcb.12602

Patil RH, Laegdsmand M, Olesen JE \& Porter JR 2013. Soil temperature manipulation to study global warming effects in arable land: Performance of buried heating-cable method. Environment and Ecology Research 1, 196-204. http://dx.doi.org/10.13189/eer.2013.010402

Poeplau C, Kätterer T, Leblans NIW \& Sigurdsson BD 2016. Sensitivity of soil carbon fractions and their specific stabilisation mechanisms to extreme soil warming in a subarctic grassland. Global Change Biology (in press), http://dx.doi.org/10.1111/gcb.13491

Rustad LE 2001. Global change: Matter of time on the prairie. Nature 413, 578-579. http://dx.doi.org/ 10.1038/35098162

Rustad LE 2008. The response of terrestrial ecosystems to global climate change: Towards an integrated approach. Science of the Total Environment 404, 222-235.

http://dx.doi.org/10.1016/j.scitotenv.2008.04.050

Scharlemann JPW, Tanner EVJ, Hiederer R \& Kapos V 2014. Global soil carbon: Understanding and managing the largest terrestrial carbon pool. Carbon Management 5, 81-91.

http://dx.doi.org/10.4155/cmt.13.77

Schindlbacher A, Schnecker J, Takriti M, Borken W \& Wanek W 2015. Microbial physiology and soil $\mathrm{CO}(2)$ efflux after 9 years of soil warming in a temperate forest - No indications for thermal adaptations. Global Change Biology 21, 42654277.

http://dx.doi.org/10.1111/gcb.12996

Sigurdsson BD 2001. Environmental control of carbon uptake and growth in a Populus trichocarpa plantation in Iceland. Ph.D. thesis. Swedish University of Agricultural Sciences, Uppsala, Sweden, $64 \mathrm{p}$.
Sigurdsson BD \& Magnusson B 2010. Ecosystem respiration, vegetation development and soil nitrogen in relation to breeding density of seagulls on a pristine volcanic island, Surtsey, Iceland. Biogeosciences 7, 883-891. http://dx.doi.org/10.5194/bg-7-883-2010

Sigurðsson BD, Elmarsdóttir Á \& Magnússon B 2005. Áhrif skógræktar á sýrustig jarðvegs og gróðurfar (Effects of afforestation on soil $\mathrm{pH}$ and ground flora]. In: Rit Fræeðapings landbúnaðarins, Reykjavík, 3. - 4. febrúar 2005. BÍ, LbhÍ, L.r., S.r., pp 303-306. [in Icelandic]

Sigurdsson BD, Medhurst JL, Wallin G, Eggertsson O \& Linder S 2013. Growth of mature boreal Norway spruce was not affected by elevated [CO2] and/or air temperature unless nutrient availability was improved. Tree Physiology 33, 1192-1205.

http://dx.doi.org/10.1093/treephys/tpt043

Snorrason A \& Einarsson SF 2002. Landsúttekt á skógræktarskilyrðum [National Inventory of Forest Production Potential]. Áfangaskýrsla 1997 - 2002 fyrir Suðurland og Suðvesturland. Rit Mógilsár 14, 68 p. [in Icelandic].

Vilmundardóttir OK, Gísladóttir G \& Lal R 2015. Between ice and ocean; Soil development along an age chronosequence formed by the retreating Breiðamerkurjökull glacier, SE-Iceland. Geoderma 259-260, 310-320.

http://dx.doi.org/10.1016/j.geoderma.2015.06.016

Way DA \& Oren R 2010. Differential responses to changes in growth temperature between trees from different functional groups and biomes: A review and synthesis of data. Tree Physiology 30, 669-688. http://dx.doi.org/10.1093/treephys/tpq015

Wetang'ula GN \& Snorrason SS 2005. Geothermal wastewater disposal: Chemical stress assessment - Lake Thingvallavatn, Iceland. In Proceedings World Geothermal Congress 2005, Antalya, Turkey, 24-29 April 2005, 15 p.

Weslien J, Finér L, Jónsson JÁ, Koivusalo H, Laurén A, Ranius T \& Sigurdsson BD 2009. Effects of increased forest productivity and warmer climates on carbon sequestration, run-off water quality and accumulation of dead wood in a boreal landscape: A modelling study. Scandinavian Journal of Forest Research 24, 333-347. http://dx.doi.org/10.1080/02827580903085171 
Woodward G, Dybkjær JB, Ólafsson JS, Gíslason GM, Hannesdóttir ER \& Friberg N 2010. Sentinel systems on the razor's edge: Effects of warming on Arctic geothermal stream ecosystems. Global Change Biology 16, 1979-1991.

http://dx.doi.org/10.1111/j.1365-2486.2009.02052.x

Porbjörnsson D, Sæmundsson K, Kristinsson SG, Kristjánsson BR \& Ágústsson K 2009. Suðurlandsskjálftar 29. maí 2008. Áhrif á grunnvatnsborð, hveravirkni og sprungumyndun [The South Iceland earthquake on 29th of May 2008. Impacts on groundwater levels, activity of geothermal hot-spots and creation of seismic cracks]. Rep. No. ÍSOR-2009/028. Unnið fyrir Orkuveitu Reykjavíkur, Iceland Geosurvey, Reykjavik, Iceland, 42 p. [In Icelandic]

Manuscript received 24 September 2016 Accepted 2 December 2016 